\title{
Justice \& Racial Conciliation: Two Visions
}

\section{Citation}

Shelby, Tommie. 2011. “Justice \& Racial Conciliation: Two Visions.” Daedalus 140 (1) (January): 95-107. doi:10.1162/daed_a_00062.

\section{Published Version}

10.1162/daed_a_00062

\section{Permanent link}

http://nrs.harvard.edu/urn-3:HUL.InstRepos:34253788

\section{Terms of Use}

This article was downloaded from Harvard University's DASH repository, and is made available under the terms and conditions applicable to Other Posted Material, as set forth at http:// nrs.harvard.edu/urn-3:HUL.InstRepos:dash.current.terms-of-use\#LAA

\section{Share Your Story}

The Harvard community has made this article openly available.

Please share how this access benefits you. Submit a story.

\section{Accessibility}




\title{
Justice \& Racial Conciliation: Two Visions
}

\author{
Tommie Shelby
}

TOMMIE SHELBY is Professor of African and African American Studies and Professor of Philosophy at Harvard University. His recent publications include $W e$ Who Are Dark: The Philosophical Foundations of Black Solidarity (2005) and "Justice, Deviance, and the Dark Ghetto," Philosophy \& Public Affairs (2007). He is also the coeditor of the magazine Transition.
M any Americans, from all racial backgrounds, are rightly proud that their nation has elected its first black president. ${ }^{1}$ In a society long weary of its race problem, such a momentous event has led some to assert that we have, definitively, realized Martin Luther King, Jr.'s dream. King, though still reviled in some quarters, is widely regarded as one of the founders of our new post-segregation republic. His interpretation of the American dream is a touchstone for measuring racial progress in the post-civil rights era. It is therefore an appropriate time to revisit Dr. King's vision for race relations in U.S. society.

Indeed, Obama is frequently compared to King. Some of the comparisons flatter the president; others do not. However, I will not weigh side by side the personal character or practical achievements of the two men. Clearly, both leaders are highly educated and charismatic; both have a gift for oratory and the ability to inspire; and both have made indelible marks on U.S. history. But because of differences in their respective vocations - mass movement leader and minister, on the one hand; Democratic Party politician and elected official, on the other - and because Obama is operating within a very different historical context than did King, any such comparison is likely to be misleading and unfair. Yet we can reflect on, and learn from, these figures' respective visions for American race relations. With this purpose in mind, I focus on ideas, on the philosophy that

(C) 2011 by the American Academy of Arts \& Sciences 
Justice should underpin political practice. My

$\&$ Racial primary concern is the mounting influence of a particular vision of race in the United States, one that I believe deserves more skepticism, or at least much less enthusiasm, than it is currently receiving.

Any vision for race relations in America should first be rooted in an honest and historically informed assessment of existing racial realities. Second, it should outline basic ideals, the intermediate and ultimate goals for which we ought to strive. Finally, the vision should specify the means by which we are to realize its stated ideals given prevailing racial realities. I am not interested in utopian fantasies but in realistic ideas. Though they often speak of their "dreams" and "hopes," King and Obama are both practical thinkers. Their writings and speeches on race explain where we are (including how we got here), where we should be going, and how we can get there. Their visions have much in common. But Obama's vision, politically shrewd and pragmatic though it may be, is marred by its defective moral content. Comparing his vision with King's reveals this deficiency.

$\mathrm{I}_{\mathrm{n}}$ n his famous "I Have a Dream" speech (1963), King described the racial realities of his day. ${ }^{2}$ He emphasized that although slavery in the United States had ended one hundred years before, black Americans were still not free. Life chances for blacks were severely diminished, "crippled" by racial segregation and widespread discrimination. Blacks were mostly poor despite living in a society with tremendous wealth. A great many were socially marginalized and isolated in slums. Blacks did not have equal citizenship because they were denied the rights to vote and hold public office. They were victims of police brutality and vicious acts of domestic terrorism. Under constant assault by racist ideology, blacks struggled to maintain self-respect and self-esteem.

The Civil Rights Act (1964) and the Voting Rights Act (1965) helped to break through the legal barriers to black inclusion in American social life, to curb discrimination, and to empower blacks politically. King thus proclaimed in Where Do We Go from Here? (1967) that many whites had come to accept racial equality, at least in principle, and to reject de jure segregation and discrimination. $\mathrm{Nev}$ ertheless, troubling racial disparities - in income, education, wealth, employment, health, and poverty - caused by continuing discrimination and centuries of gross mistreatment and abuse, remained unaddressed. He argued that racist opposition was not the only reason these disparities had yet to be met with an adequate response. An equally if not more difficult obstacle was that most whites, even many who rejected racism, resisted racial justice measures that might have a personal cost. As King wrote, "The great majority of Americans ... are uneasy with injustice but unwilling yet to pay a significant price to eradicate it."3 In response to this resistance, King reminded us that meaningful attempts to bring about a just society have unavoidable costs. Quality education for all children, decent and well-paying jobs for adults, and the eradication of slums for the benefit of the poor require great resources.

King was committed to the fundamental ideals of racial equality and integration. He understood the former as a demand of social justice that could be described in terms of two principles. First, each citizen, regardless of his or her race, should enjoy equal civic standing and the equal protection of the law. Justice does not permit second-class citizenship on the basis of race. Second, government should ensure that no one's basic rights are curtailed or general life prospects 
reduced because of the racial prejudice of others. It is not enough that the state refrain from treating some citizens as if they were civic inferiors unworthy of equal concern and respect. Private individuals and associations must be made to follow suit, at least when individuals' basic liberties or vital socioeconomic opportunities are at issue.

Moving toward racial equality required a concrete policy of desegregation. The primary goal of desegregation was to abolish the unfair exclusions and prohibitions of Jim Crow, a social system that gave whites privileges and advantages they did not merit, deprived blacks of rights and opportunities they deserved, and generally stigmatized black people as inferior. To end discrimination in housing, education, employment, and lending, nondiscrimination laws needed to be enacted and scrupulously enforced. In the political sphere, achieving racial equality meant granting blacks the unfettered right to vote and hold political office.

The civil rights movement, through litigation and persistent pressure on Congress and several presidents, abolished a hideous and terrifying race-based regime. Previously, the subordination of blacks was the law of the land in the South, and discrimination against blacks was widespread throughout the country. Many, then and now, see this tremendous victory as the end of the struggle for racial equality. King did not share this view. He recognized that the many decades of slavery and Jim Crow had severely disadvantaged blacks (especially in education, employment, wealth, and housing) and had injured their self-respect and psychological well-being. Even if the new civil rights laws were impartially and effectively enforced, the damage inflicted by the long reign of white supremacy would remain. Repairing it was an urgent issue of racial justice. Certainly, in a market society, where competition determines Tommie Shelby most people's life prospects, "the pursuit of happiness" as an equal right of all citizens would not be guaranteed until blacks were no longer handicapped by the legacy of white domination.

According to King, justice, in its most basic sense, means giving persons what they are due. Fulfilling this demand often means treating everyone the same. But sometimes it calls for treating people differently. This point has particular relevance with regard to serious injustices, whereby a certain class of persons has suffered mistreatment and is disadvantaged as a result. As King says in Why We Can't Wait (1963), “[O]ur society has been doing something special against the Negro for hundreds of years. How then can he be absorbed into the mainstream of American life if we do not do something special for him now, in order to balance the equation and equip him to compete on a just and equal basis?"4 Many people - perhaps relying on the familiar line about being judged by the content of one's character rather than by one's skin color - wrongly believe that King rejected reparations and all other race-targeted, compensatory measures for black Americans. In fact, he supported such recompense:

Few people consider the fact that, in addition to being enslaved for two centuries, the Negro was, during all those years, robbed of the wages of his toil. No amount of gold could provide an adequate compensation for the exploitation and humiliation of the Negro in America down through the centuries. Not all the wealth of this affluent society could meet the bill. Yet a price can be placed on unpaid wages. The ancient common law has always provided a remedy for the appropriation of the labor of 


\footnotetext{
Justice

\& Racial

Conciliation
}

one human being by another. This law

should be made to apply for American

Negroes. The payment should be in the

form of a massive program by the government of special, compensatory measures which could be regarded as a settlement in accordance with the accepted practice of common law. 5

In addition to the ideal of racial equality, King advocated integration. From a political perspective, integration is linked to the requirements of justice. Certainly, blacks and other racial minorities should not be formally excluded from participating in the social, economic, and political life of the nation. But these previously excluded groups should also be actively included as equal and indispensable participants. Such inclusion should not amount to tokenism, in which a small non-white elite is created, integrated, and made to represent symbolically the "progress" of their respective groups, leaving most in those factions still socially marginalized and politically powerless. Justice requires that whites fully share power and decision-making with non-whites, erasing all signs of white domination. The members of different racial groups must ultimately recognize their mutual dependence and equal status; they must solve their problems together. Integration, in this sense, is the realization of the republican ideal of collective self-determination in a multiracial society.

King was also intensely concerned with the ethical side of integration. In "The Ethical Demands for Integration” (1962), he explained that our goal should not be mere desegregation and nondiscrimination. ${ }^{6}$ Rather, we must aim to build a society in which the members of different races have a sense of goodwill toward one another and think of themselves as collectively constituting one people. We should not be content with interracial détente; we should strive for interracial civic friendship - that is, fraternity in a multiracial society of equals. This unity should be founded on mutual respect and understanding. King evokes the ethical dimension of integration in his memorable line, "I have a dream that one day on the hills of Georgia, sons of former slaves and sons of former slave-owners will be able to sit down together at the table of brotherhood."7

The goal of mere desegregation is deficient in part because it suggests that we should be satisfied if nondiscrimination laws are obeyed out of prudence (to avoid legal sanctions, for example) or out of general respect for the law. For King, it was crucial that we obey these laws not simply because we fear punishment or recognize the authority of law, but because such laws are morally right: because they embody the worthy ideal of integration.

Racial equality and political integration, King insisted, were pressing matters of justice and thus enforceable through law. On the other hand, he did not believe that the ethical ideal of interracial unity could be enforced. Implementing legislation, along with its steadfast enforcement, is definitely essential to regulating the behavior of those who refuse to respect the demands of justice. Furthermore, a racially just polity is a necessary condition for genuine interracial fraternity. However, trust, respect, and mutual concern cannot be achieved through law enforcement. A complete resolution of the race problem in America therefore requires that each individual willingly commits to integration.

To achieve his stated ends, King supported militant mass protest. He believed in uncompromising dissent from and active agitation against racial injustice. This resistance should take the form of 
organized boycotts, civil disobedience, and public demonstrations. These tactics sought to highlight egregious wrongs and expose hypocrisy, to awaken and motivate the morally complacent majority, and to put economic and political pressure on those with the power to change conditions. King is part of a long and venerable tradition of freedom fighters who fervently believe that injustices are never corrected without the determination and hard work of individuals openly fighting together for what is right.

King held central the precept that in the struggle to achieve racial equality and integration, we must use means that are as pure as the ends we seek. The principle "by any means necessary" was not to his mind a morally permissible stance, even for a severely oppressed people. Moreover, he was convinced that morally suspect measures could never realize our ideals; the ethical means available were sufficient. King further cautioned against destroying our chances of reaching our ultimate goals by using means designed to secure short-term or intermediate ends.

For these reasons, King believed that the fight for racial justice and integration must be nonviolent. He frequently admonished blacks to reject political violence and not to succumb to hatred and blanket mistrust of whites. To be sure, violent resistance would be ineffective: blacks lacked the resources and tactical means to win a confrontation with white racists; black aggression would give white supremacists an excuse to slaughter blacks not in the movement, thus undermining black communal support; and violence would alienate needed white allies and obscure the moral issues the struggle meant to highlight. King also objected to political violence on moral principle. Such tactics were simply wrong, regardless of whether they could secure concessions from those in power. Even if political violence could achieve some intermediate goals - such as curbing poTommie Shelby lice brutality and discouraging white terrorism - it would undermine the ultimate goal of interracial fraternity.

King also rejected black separatism, not only as an ideal but as a means to black liberation. Undertaking the struggle for racial equality and integration demanded interracial cooperation. Beyond the pragmatic point that blacks could not succeed alone, King objected to racial separatism on moral grounds. Not all whites are untrustworthy or malicious, he contended, and blacks should not treat them as if they were. To reject white participants in the movement would dishonor those whites who made great sacrifices - including the ultimate sacrifice - in the pursuit of racial justice. Moreover, interracial fraternity will arrive only after the various racial groups in America recognize that they have a "common destiny": to live together as one people. Such mutual understanding and respect between the races can come about only through frequent contact and cooperation. In Where Do We Go from Here? King makes this point forcefully and eloquently: "Since we [black people] are Americans the solution to our problem will not come through seeking to build a separate black nation within a nation, but by finding that creative minority of the concerned from the oft-times apathetic majority, and together moving toward that colorless power that we all need for security and justice." 8

$\mathrm{I}_{\mathrm{n}}$ those focused on race), Obama frequently invokes, explicitly and implicitly, King's dream for America. ${ }^{9}$ He endorses King's ideals of racial equality and integration, regarding an end to discrimination and prejudice, the elimination of racial disparities, and interracial unity as ultimate 
Justice \& Racial Conciliation and detractors, for that matter - view his ascent to the presidency as confirmation that the bounced check King lamented has finally been cashed, and that we now live in a "post-racial" society, Obama has consistently cautioned against this interpretation of current racial realities. In The Audacity of Hope (2006), for example, he writes, "[T] o say that we are one people is not to suggest that race no longer matters - that the fight for equality has been won, or that the problems that minorities face in this country today are largely self-inflicted."10

In "A More Perfect Union" (2008), the famous speech Obama delivered in Philadelphia ("the city of brotherly love"), he forthrightly stated that, while we have made undeniable progress, the problem of race has not been solved..$^{11}$ Existing racial disparities - in education, wealth, and income - are, he claims, in part the debilitating consequences of slavery and Jim Crow. Pervasive discrimination in the past - in housing, employment, and lending - explains the current racial disparities in wealth and income. The fact that blacks were prevented from amassing assets they might pass on to their children largely accounts for urban and rural poverty. As he observed in his remarks at the 2009 NAACP Centennial Convention, the highest barriers to racial equality today are the structural inequalities that are the legacy of racial injustice in the United States. ${ }^{12}$

Indeed, while Obama often emphasizes how the injustices of the past still shape our present, he also highlights current racial injustices. In The Audacity of Hope, he explains how degrading racial stereotypes and unconscious bias lead to discrimination in employment and law enforcement. In his controversial statements about the arrest of Professor Henry Louis Gates, Jr. - remarks that, in his haste to quell the controversy, he did not retract - Obama made it clear that he believes racial profiling of blacks and Latinos remains a serious problem. He has publicly registered his opposition to a recent immigration law, passed in Arizona in April 2010, on the grounds that it will invite racial profiling and harassment of Latinos. In his Philadelphia speech on race, he called the racial achievement gap a result of the segregated and inferior public schools that serve minorities. Black families are often weak or broken not just because of irresponsible fathers, but because black men have been denied equal economic opportunity. He claimed that a lack of basic public services in poor black neighborhoods (effective law enforcement, parks, regular garbage pick-up, and building-code enforcement, for example) has fostered urban violence and blight. Though some blacks, he noted, have heroically triumphed over many obstacles to succeed (sometimes aided by affirmative action policies), others have been unable to defeat these unfair odds. Instead, they often dwell in our deteriorated urban centers or languish in our prisons without hope or prospects.

What is to be done? As Obama said on the one hundredth anniversary of the establishment of the oldest civil rights organization in America, " $[\mathrm{T}]$ he first thing we need to do is make real the words of the NAACP charter and eradicate prejudice, bigotry, and discrimination among citizens of the United States." He has also consistently made clear the need to vigorously enforce nondiscrimination and civil rights laws. In other words, a person's ability to acquire a stable and wellpaying job, decent and affordable housing, credit at fair interest rates, or quality education should not be hampered by the racial prejudice and bias of others. Moreover, it is the responsibility of gov- 
ernment to ensure that this principle is realized; market forces are not sufficient. Obama also believes that we must guarantee fairness and impartiality in our criminal justice system. Due process is a basic civil right, and racism, whether conscious or not, must not be allowed to abridge this fundamental liberty.

How are we to respond to the racial disparities and inherited disadvantages caused by historical injustices? Obama does not support reparations for the descendants of slaves or the victims of the segregation regime, though he concedes that affirmative action in higher education can be a useful, if limited, tool to expand opportunity for underrepresented racial minorities. Instead, he favors universal programs that aim to help all who are disadvantaged, regardless of race, over policies that aim to compensate or aid specific racial groups. Because racial minorities are disproportionately disadvantaged, he reasons, they will reap a large share of the benefits of such policies.

In The Audacity of Hope, Obama offers two reasons to explain why an emphasis on universal programs over race-specific ones makes good political sense. The first is that white guilt has run out. White Americans now resent blacks' continuing grievances and sense of victimhood. Thus, they do not support policies that grant the legitimacy of black claims of injustice. Second, whites perceive that spending our limited public resources on further attempts to create racial equality or end ghetto poverty runs contrary to their self-interest. Such efforts not only mean higher taxes; they mean fewer public resources to aid whites. Obama concludes that policies to help all in need which would, in theory, disproportionately aid racial minorities - should be favored in the current context. He believes universal policies will more likely garner multiracial support, including white support. Like King, Obama is Tommie Shelby convinced that we cannot establish a just society without interracial cooperation. Thus, we must chart a course to bridge the racial divide and foster racial conciliation.

But there are further obstacles to the realization of this vision, and Obama is keenly aware of them. In "A More Perfect Union," he explained that as a result of our history of racism and the pain it has caused, many blacks remain angry at times, bitter. Though sometimes justified, anger can be counterproductive. Not only can it blind blacks to their responsibility to improve their own condition, but it can prevent the formation of interracial alliances essential for real social change. Obama noted that some working- and middle-class whites are angry, too. They do not believe they are privileged by their race; they believe they have earned everything they have. They were not the ones who committed the injustices against blacks and thus feel no obligation to correct historical wrongs. Besides, they face serious economic challenges of their own, challenges that threaten their hopes and dreams. They resent when desegregation efforts mean their children are bused to schools outside their neighborhoods; when affirmative action allows racial minorities to gain advantages in employment and education; and when they are accused of racism for expressing fears about black crime.

As with black anger, Obama insists that white resentment toward racial minorities is often counterproductive. It distracts, he said, from the "real culprits" behind the economic insecurity that all working- and middle-class people experience: namely, a corporate culture of greed, a government that answers to corporate interests but is unresponsive to the needs of ordinary citizens, and eco- 
Justice nomic policies that favor the wealthy. At

\& Racial times, Obama seems committed to an

Conciliation underlying social theory that considers it counterproductive to challenge whites directly for clinging to racist ideologies. These ideologies, so the theory goes, are ultimately rooted in a widespread sense of economic insecurity and political powerlessness among whites. It is better to attack the roots of the problem - corporate dominance over our lives and our democracy - without condemning whites for harboring racist attitudes and accepting racial stereotypes. If, through interracial cooperation and collective resolve, we fix these underlying problems, then this kind of racism should, more or less, take care of itself. In the meantime, we shore up enforcement of nondiscrimination laws so that blacks and Latinos are protected from the most serious consequences of white racism.

Obama thinks we can, or at least should, set aside old racial divisions and work together to achieve common goals. For blacks, such cooperation is not possible without equal citizenship and just treatment in all dimensions of American life. But blacks should not insist that their particular grievances be addressed independently of measures designed to ensure justice and opportunity for all. There are non-blacks, including whites, who also need government to protect them and provide economic opportunity. He calls on the white community to acknowledge that black disadvantage is caused in part by discrimination, past and present. Nonetheless, he thinks we should address these inequities not through race-specific policies but through enforcement of nondiscrimination laws and universal policies that create more opportunity for all.

The famous Philadelphia speech on race ends with an anecdote about two campaign workers, one white and one black, a story Obama says he first told on King's birthday at Ebenezer Baptist Church, where both King and his father had served as pastor. The lessons we are to take from the story are, I believe, these: whites who lack economic security should not blame blacks and Latinos but, rather, should seek them out as allies against the injustices caused by corporate greed, corrupt political leadership, and the superwealthy who want to keep all benefits of economic growth for themselves and their progeny; blacks and Latinos, in turn, should not allow their racial grievances and sense of victimhood to prevent them from forming productive alliances with whites who have similar problems.

$\mathrm{O}$ bama's fundamental goals of racial equality and integration are worthy. Moreover, his assessment of current racial realities and their historical roots is, I believe, accurate. However, I am troubled by his proposed way forward. I see four related problems, all of which stem from Obama's failure to heed King's precept: to use means as pure as our ends.

First, Obama asks blacks to shoulder too much of the burden of racial conciliation and demands too little of whites. Indeed, in the name of interracial unity, his approach would actually reward white resistance to racial-justice measures. Second, Obama's vision would require that we use morally suspect tactics, including compromising with, and remaining silent in the face of, injustice and racial prejudice. Third, setting aside their questionable moral standing, the means Obama advocates are not aligned with his stated ends of racial equality and interracial fraternity, appearances notwithstanding. Finally, his strategy, though perhaps it would secure some intermediate and worthwhile goals, might inhibit our ability to reach the ultimate objectives of racial justice and interracial comity. 
Obama has consistently stated that both current discrimination and the legacy of past discrimination help explain existing racial inequalities and black disadvantage, and he believes these injustices have not been adequately addressed. If this interpretation is correct, then blacks' sense of grievance - their continuing anger - is warranted. Of course, when this anger becomes rage and thus leads to cathartic violence or irrational hatred of all whites, which it sometimes has, it is not just counterproductive but abhorrent. It is not hard to see why whites would be put off by such anger, especially those with a demonstrated commitment to racial justice. But when properly targeted and proportionate to the wrong that has elicited it, anger can be politically constructive and a healthy sign of self-respect. It can open one's eyes to similar injustices suffered by others; it can inspire one to take action; and, when understood to be widely shared, it can lead to collective mobilization. Indeed, a lack of anger among persons unfairly treated and burdened by injustice would be disquieting, suggesting that the afflicted had either given up hope or lacked self-respect, that they had succumbed to cynicism or surrendered to injustice, and that they had ceased to put up a fight. Justified indignation should not alienate whites. And if whites respond to this kind of anger with resentment toward racial minorities, dismissing their just claims for redress as a desire for handouts or excuses for their own failings, then the darker races should be angry about this reaction, too, and deeply suspicious.

I suspect that some of the opposition to racial justice measures runs deeper than the desire of economically vulnerable whites not to lose further ground in an economy that no longer satisfactorily rewards their hard work. It also springs from their desire to keep racial minori- ties in a subordinate or disadvantaged position in relation to whites as a group. Tommie Shelby Though they are reluctant to admit it publicly (and maybe even to themselves), some whites seem determined to hold on to their comparative advantages; they view policies that promote the cause of racial justice as threats to white dominance. ${ }^{13}$ On grounds of self-respect, blacks should not seek a political solution to the problem of racial inequality that compromises with or yields ground to this sentiment. This attitude must not be accommodated, worked around, or ignored.

In both "A More Perfect Union" and The Audacity of Hope, Obama rightly points out that Republican politicians and right-wing demagogues have long exploited white anger over welfare and affirmative action and white fear of black crime. Where he falters is in failing to hold accountable working-class whites who scapegoat blacks and Latinos for problems caused by corporate and political elites. He might believe such scapegoating is racist; calling it racist, however, might seem unwise or divisive. Perhaps he is simply counseling disadvantaged racial minorities to swallow their anger, bite their tongues, and console themselves with the thought that economic causes underlie resentment toward nonwhites. He wants racial minorities to recognize what they share with low- to moderate-income whites: a common interest in altering these damaging economic forces.

However, it is unreasonable and impractical to expect racial minorities simply to overlook or excuse such racist attitudes. How can they regard reactionary whites as allies if these whites will not confront their own racism? How can people of color work together with whites who believe that blacks and Latinos have caused the economic problems that the 
Justice white working class faces? Whites who \& Racial scapegoat darker peoples do not yet see Conciliation who the common enemy is; therefore, they cannot be relied on as allies in the fight against that enemy. In this way, Obama's compromise with white racial resentment cannot achieve his stated aim of interracial unity.

But let us suppose that this kind of racism is a minor problem, one that can be adequately contained with vigorous enforcement of civil rights laws. The real problem, Obama might argue, is that many whites believe that policies aimed at correcting racial injustices are contrary to their economic self-interest. They harbor no ill will toward racial minorities; nor are they attracted to white nationalist ideas. They simply do not want to pay the costs associated with fighting or correcting racial injustice.

As King emphasized, we cannot possibly realize our ultimate ideals if we allow this stance to reign unchallenged. We all must accept that justice, including the correction of injustice, comes at a cost though one well worth paying. Any effort to respond effectively to racial injustice will inevitably cost whites something. Indeed, it will cost many racial minorities as well. For example, given residential segregation patterns, there is no way to abolish de facto segregated schools without either integrating neighborhoods or busing some students to schools outside their neighborhoods. Why should all the kids who are bused be racial minorities? Though it would mean abandoning King's ethical ideal of integration, we could try to improve urban public schools without regard to their racial makeup, but that would take a lot of resources, which means higher taxes, including higher taxes for whites.

Many whites dislike affirmative action policies because such measures offend their sense of fairness. ${ }^{14}$ But if we aban- don that set of policies (which some states already have), then any serious effort to deal with black educational and employment disadvantages will require us to devote more resources to the task, which again means higher taxes, including higher taxes for whites. These costs cannot be escaped - at least not if we intend to take racial justice seriously. One response, not without merit, is to insist that the wealthy should bear these financial burdens; those who are themselves struggling economically should not. This tactic would mean collectively pushing for a more progressive tax scheme and higher estate taxes. But many middle-class and working-class whites do not favor this approach either; presumably, they doubt they would benefit from such efforts - though some might say it has more to do with their legitimate opposition to "big government."

Obama's response to this political reality is to combat the legacy of racial injustice by advocating universal measures that aim to help the members of all racial groups, including whites. The idea is that if whites will benefit, and the policies are not explicitly tailored to aid or appease "angry" racial minorities, we can gain greater support for progressive goals. But even with backing from a number of whites, this strategy would intentionally obscure the morally important difference between creating more opportunity for all and remedying the effects of past racial injustices. From a moral point of view, these are not the same goals, even though they are compatible and might both be furthered by the same policy. Obama advocates universal policies that he believes would, as a by-product, reduce glaring racial disparities. But he purposefully refrains from construing these policies as racial redress. Therefore, whites are not required to concede the legitimacy of 
blacks' grievances. To establish genuine racial conciliation, though, whites must willingly support policies that reduce racial inequality because doing so is what racial justice demands.

Some would reply that if universal policies will reduce racial disparities and improve the lives of minorities, there is no good reason to insist that race-specific policies be used instead. But the question is not which policies will most effectively reduce racial inequality; rather, it is why race-targeted policies are off the table. There is nothing intrinsically wrong with policies designed to help specific groups of people rather than everyone. From the standpoint of justice, we should not have to conceal the intent behind the implementation of such policies. Sometimes specific classes of persons (women, disabled persons, immigrants, rural residents, victims of natural disasters, and so on) have needs that require specially tailored remedies. Indeed, so-called universal policies are not really universal since they are not meant to help everyone, just those who have been socioeconomically disadvantaged by recent government action and changes in the structure of the economy. It is at least possible that the black urban poor is another group in need of special intervention. Again, it seems that the only reason to preemptively rule out such remedies is that they would arouse the unjustified hostility of many whites.

Nor is the issue whether specific policies should be unmistakably labeled "for poor black people" or "to reduce racial disparities." Policies designed to help all those who are unfairly disadvantaged, regardless of race, are also justified and, given the overlapping interests involved, no doubt easier to enact. In our determination to heal black wounds, we must not ignore the fact that others are suffering, too. As King reminds us: "As we [black people] work to get rid of the economic strangulation that we face as a reTommie sult of poverty, we must not overlook the fact that millions of Puerto Ricans, Mexican Americans, Indians and Appalachian whites are also poverty-stricken. Any serious war against poverty must of necessity include them." 15 Rather, the issue is whether we can openly defend a policy on the grounds that it is, at least in part, a response to racial injustice and still garner wide support for it. If we cannot generate such support, especially among whites, what does such an outcome say about the state of race relations and the possibility for further racial progress in this society? If we have good reason to suspect that a significant number of whites seek to hold on to their advantages despite the fact that some of these have been gained because of a history of racial injustice - or, worse, that a significant number of whites want to keep racial minorities trapped in an inferior social position, then people of color have reason to resent this lack of support and to withhold solidarity from those who would deny them what they are due.

Moreover, we should not have to pay off - in essence, to bribe - the white majority in order to secure justice for racial minorities. Already, many whites refuse to accept the costs associated with achieving racial justice. Now, in order to reduce racial inequalities caused by nearly four centuries of injustice, we must adopt only those measures that provide whites with material benefits? The moral perversity of this approach should be readily apparent. Blacks ought to demand that their fellow citizens not only acknowledge that black disadvantages are caused, at least in part, by past and ongoing injustices a position that Obama himself articulates - but they should also continue to insist that their fellow citizens demonstrate a commitment to remedying these 
Justice disadvantages, even if the necessary

$\&$ Racial remedies do not benefit these citizens

Conciliation directly. This admittedly difficult route is the only path to true racial conciliation. There is no bypass.

If vision is less about achieving racial justice and interracial fraternity than simply making disadvantaged racial minorities somewhat better-off materially using whatever means, morally tainted or not, that are available - his vision has obvious merit. It offers a pragmatic strategy for navigating hazardous racial waters in a way that could improve the socioeconomic circumstances of disadvantaged racial groups. If this political maneuver works, numerous people, including many members of racial minority groups, will receive much-needed help.

However, if Obama's racial philosophy is to be understood as an updated version of King's vision - a recalibration to fit the racial realities of our time - then it leaves much to be desired. Judged alongside King's transformative vision of racial equality and integration, Obama's philosophy is morally deficient and uninspiring. Relying as it does on dissimulation and subtle bribes, it does not keep faith with King's precept: to use means as pure as our ends. Obama's vision would ask racial minorities to give up on true racial equality and to form bonds of solidarity with whites who refuse to recognize blacks' legitimate demands for redress. It fails to insist that whites carry their fair share of the burden to end racial inequality. And it tries, futilely, to build interracial fraternity on the basis of overlapping material interests rather than on a shared commitment to justice.

Perhaps we should not expect Obama to be a moral leader on issues of race. After all, he is a black elected official who largely depends on other elected officials to enact domestic policy. He is therefore constrained by a sometimes recalcitrant and racially divided populace. It is no doubt difficult to insist that one's fellow citizens rise above their unjustified anger, prejudices, and selfishness if, to get their votes and campaign donations, one must remain silent in the face of, or even reward, these very attitudes. That Obama has not openly defended the need to reduce racial inequality and ghetto poverty on grounds of justice but has instead relied on stealth methods and "universal” policies is revealing. It shows that he believes he must accommodate race-based hostility and illegitimate white group interests to make modest improvements in the lives of disadvantaged racial minorities. Regrettable and distasteful as it is, perhaps this is the price that must be paid to protect the weak and vulnerable from grave harm. But such actions should be seen for what they are: moral compromises necessitated by the imperative to meet urgent needs. They should not be cast or interpreted as rectifications of racial injustice or stepping-stones to interracial fraternity.

\footnotetext{
ENDNOTES

${ }^{1}$ For helpful feedback on earlier drafts, I thank Lawrence Blum, Gerald Early, Andrew Fine, Lani Guinier, Randall Kennedy, Lionel McPherson, and Jessie Scanlon.

${ }^{2}$ Martin Luther King, Jr., "I Have a Dream,” in A Testament of Hope: The Essential Writings and Speeches of Martin Luther King, Jr., ed. James M. Washington (New York: HarperCollins, 1991), $217-220$.
} 
3 Martin Luther King, Jr., Where Do We Go from Here: Chaos or Community? (Boston:

4 Martin Luther King, Jr., Why We Can't Wait (New York: Signet Classic, 200o), 124; emphasis in the original.

5 Ibid., $127-128$.

6 Martin Luther King, Jr., “The Ethical Demands for Integration,” in A Testament of Hope, ed. Washington, $117-125$.

7 King, “I Have a Dream,” in A Testament of Hope, ed. Washington, 219.

8 King, Where Do We Go from Here, 54.

9 I should clarify my interpretive method used in analyzing Obama's vision. It is generally understood that in order to be elected and stay in office, politicians often use deceit; sometimes they lie. For the purposes of this essay, I take Obama's considered public statements at face value. I assess the vision itself, a vision that many, including many racial minorities, support or find attractive. I make no claims about whether the vision is offered in good faith, about the authenticity of Obama himself, or about the extent to which his actual policy choices and political tactics square with his stated vision.

10 Barack Obama, The Audacity of Hope: Thoughts on Reclaiming the American Dream (New York: Crown, 2006), 232.

11 The speech, both in transcript and video form, can be found at http://www .barackobama.com/speeches/.

${ }^{12}$ An official transcript of the speech can be found at http://www.whitehouse.gov/ the_press_office/Remarks-by-the-President-to-the-NAACP-Centennial-Convention $-07 / 16 / 2009 /$.

13 This claim is not uncontroversial, but it does have substantial empirical support. See Donald R. Kinder and Lynn M. Sanders, Divided By Color: Racial Politics and Democratic Ideals (Chicago: University of Chicago Press, 1996); Jim Sidanius and Felicia Pratto, Social Dominance: An Intergroup Theory of Social Hierarchy and Oppression (Cambridge: Cambridge University Press, 1999); David O. Sears, Jim Sidanius, and Lawrence D. Bobo, eds., Racialized Politics: The Debate about Racism in America (Chicago: University of Chicago Press, 200o); Lawrence D. Bobo and Mia Tuan, Prejudice in Politics: Group Position, Public Opinion, and the Wisconsin Treaty Rights Dispute (Cambridge, Mass. : Harvard University Press, 2006).

14 The case that affirmative action is not unfair is forcefully made in Bernard R. Boxill, Blacks and Social Justice, rev. ed. (Lanham, Md.: Rowman \& Littlefield, 1992), chap. 7 ; and Ronald Dworkin, Sovereign Virtue: The Theory and Practice of Equality (Cambridge, Mass. : Harvard University Press, 2000), chaps. 11-12.

15 King, Where Do We Go from Here, 132. 